\title{
The Influence of the Symbols of Virtue on Maturity in The Alchemist
}

\author{
Dara Elizabet Alinda \\ Balikpapan University \\ elizabetalindad@gmail.com \\ Wahyuni \\ Balikpapan University \\ wahyuni@uniba-bpn.ac.id \\ Adi Prautomo \\ Balikpapan University \\ Adi.prautomo@uniba-bpn.ac.id
}

\begin{abstract}
:
A virtue is trait of mind and character that help people achieve a good life and sometimes a virtue can be found in the symbols. The symbols of the virtue can have an effect on a person's maturity in thinking and acting. The theory used in this research is the semiotics approach by using theory of Charles Sanders Peirce about triangle theory, there are representamen or sign, object and interpretant. The methodology used in this study is descriptive qualitative research to explain the data, because the data are analyzed in the form of words and sentences. The data are taken from the sentences and the conversation in the text in The Alchemist by Paulo Coelho. The result of this research is the researcher found the symbols of the virtue such as six of the character symbols and one the object symbols. The symbols are explained with the process of semiotic theory called triadic process, from this process the researcher can determines the maturity of the main character based on seven criteria of maturity.
\end{abstract}

Keywords: symbols, virtue, maturity, The Alchemist

\section{INTRODUCTION}

The literature is an art form of the word which can be expressed both in oral and written. Generally, the term "literature" is used to describe anything from creative writing to more 
technical or scientific works, but the term is most commonly used to refer to works of the creative imagination, including works of poetry, prose, drama, fiction, and nonfiction. Literature is an interesting subject to be studied. It discusses about the picture of human life. In studying of literature, the reader combines his emotion, imagination, and logic. It helps the reader to think personally and intellectually. Literary works consist of many forms such as poetry, prose, poem, novel, drama and song etc. In this research, the researcher uses a novel as the object of research, because novel is one of the forms as literary work.

Novel as a part of the fiction can be defined as a work of prose fiction, which tells story or uses incidents to dramatize human experience and individual character. Usually, the character can grow if there is a moral value within the story. In the selected novel, there is a virtue shown. Virtue is a trait of mind or character that help someone to achieve a good life, because the virtue has two types, intellectual virtues and morals virtues.

The virtues are attitudes, dispositions or characters trait that enable us to be and to act in ways that develop our potential. It can influence someone to maturity, behave better or think wisely. Maturity is not only about physical growth, but also based on the maturity of thinking and acting. In this research the idea of virtue is found in some symbols. In this research the theory used is semiotics approach by Charles Sanders Peirce about triangle theory, there are representamen or sign, object and interpretant. The theory can relate to identify the symbols of the virtue to maturity. In addition, there are seven criteria of maturity also found in this research.

\section{LITERATURE REVIEW}

\section{Semiotics by Charles Sanders Peirce}

Semiotics is a general philosophy theory related to signs and symbols as part of a code system to communicate information. Semiotics includes all visual and verbal signs. All of these signs can be accepted by all human senses when these signs or symbols form a systematic code, to convey information on human activities.

In the concept Charles Sanders Peirce offers a model that is called triadic. The central to the process of semiosis is the triadic relationship involving the sign, the interpretant, and the object. The concept of thricotomies is mentioned as follows:

1. Representative, which is commonly accepted by the sign or serve as a sign.

2. Interpretative, is not an interpreter of the sign but rather refers to the meaning of the sign.

3. Object, which is something that refers to a sign. Something that is represented by the representative relate to the references. The data object in the form of a mental representation (in mind), can also something that real outside the sign. 
Prologue: Journal on Language and Literature Vol.7 No.2 (2021)

Figure: 1 The concept of thricotomies (Rebecca Stone, 2000)

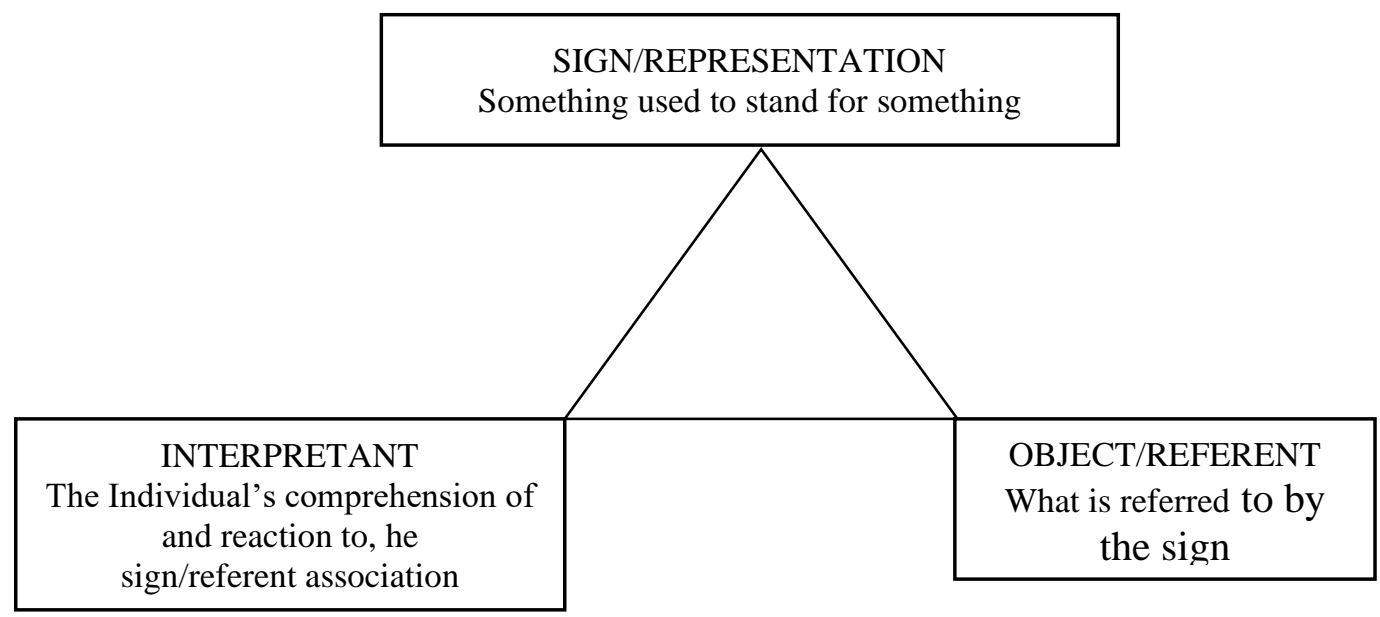

The three dimensions above always be presented in a significance. That is called the triadic structure, it looks like a triangle model.

Figure: 2 Pierce's Triangle Model (Marcel Danesi, 2011)

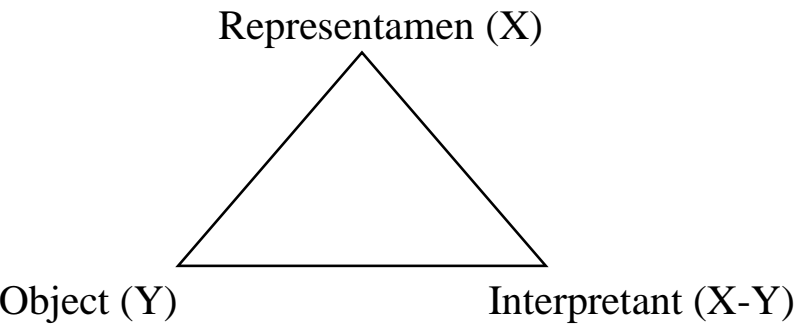

That model is also commonly referred to as the theory of triangle meaning semiotics. The signs or representamen is the first element which stands in such as genuine triadic relation to the second element that is called objects as to be capable of determining the third element, it is called interpretant to assume the same triadic relation to its object in which it stands itself to the same object.

However, if we want to do a more an in-depth analysis, we must use all levels of the sign from the first to third of trichotomies. There are three trichotomies with three levels and nine sub-types of the signs. It can be seen in the following table:

Table: 1 Pierce's Trichotomies (Detedalle in Nawiroh, 2014)

\begin{tabular}{lccc}
\hline & 1 & 2 & 3 \\
\hline Representamen (R1) & Qualisign & Sinsign & Legisign \\
Object (O2) & Icon & Index & Symbol \\
Interpretant (I3) & Rheme & Decisign & Argument \\
\hline
\end{tabular}


The meanings of the three trichotomies above are explained as follows:

The First Trichotomy based on Ground is explained in the following section.

1. Qualisign is the quality of a sign. For example, the quality of words used in accompanying the sign is like words that are hard, rough or soft. Not only words that determine the quality of a sign, it can also be the color used even the accompanying image. For example, red is a qualisign, because it can be used as a sign of love, danger and prohibition.

2. Sinsign is a sign that becomes the signs based on their shape or appearance in reality or the actuality of an object or an event of the sign. For example, a scream can be interpreted as surprised, happy or in pain. Or "flood" is an event that explains is caused by rain.

3. Legisign is the norm contained in a sign. This is related to what may and may not be done. For example, the traffic signs.

The Second Trichotomy based on the object is explained in the following section.

1. Icon is a sign that resembles the original object and can also be interpreted as a relationship between the signs and the objects that are similar. For example, a map.

2. Index is a sign that is related to things that are causal, or cause and effect. In this case the sign has a relationship with the object cause and effect. The sign means the result of a message. For example is smoke as a sign of fire.

3. Symbol is a sign that is related to signifier and signified. That something is symbolized by mutual agreement. For example, the red light means stop, everyone knows and agrees that the red light indicates stop.

The Third Trichotomy based on Interpretant is explained in the following section.

1. Rheme is a sign that can be developed. For example, someone has red eyes, he may be drowsy, or he has eye pain, irritation or he is just wake up and etc.

2. Decent sign is a reasonable sign with the facts. For example, there are a lot of children in a village street so that there are lots of children on the road and lots of children are careful.

3. An argument is a sign that contains a reason for something. For example, a smoking ban at gas stations, because gas stations are a flammable place.

\section{Virtue}

The basis of virtue ethics is the idea of eudaimonia, which means "the good life" or "life lived well" or "flourishing" or "happiness.". The other major concept of virtue ethics is that of virtue. A virtue is a trait which allows one to fulfil one's function well. Eudaimonia/living well consists in "the activity of the soul in accordance with reason." The classic "virtues" (courage, justice, temperance, prudence, generosity, compassion, etc.) are things that allow us to fulfil our function well-without developing virtues the human 
cannot live well the life of reason. The idea is, since living well is the most generic activity, the one for which the human does all other activities it will require the most general virtues. Things like courage and patience are needed to be excellent at any activities. The people are certainly needed for the activity of living life in accordance with reason.

\section{The Maturity}

Maturity is the end result of harmony between physical and psychological functions as a result of growth and development. The level in adults is the level of personal maturity, although not all adults are reaching personal maturity. Usually, a normal individual understands what they are doing and to understand of the adults cannot be known without any understanding of goals as well as aspirations. Personal that has grown up in principle must have the components as below:

1. Extension of self means that his life does not have to be tied to activities relate to the value of importance and direct duties. The most important of the extension of self is a projection to the future that are planning and expecting.

2. Self-objectification, its main components are insight and humor. Insight is an individual skill to understand himself. Humor is the ability to get pleasure and to laugh and to also maintain a positive relationship with oneself and the likes.

3. Philosophy of life means that the background that underlies everything that is done that gives it meaning and purpose.

Individuals who experience development is called mature when he is achieving something growth and development as a person who are mature and healthy. Here are seven criteria of maturity, they are:

\section{Extension of self}

When self develops, the self extends to reach many people or objects. The first, the self is only centered in the individuals, but when the circle of experience grows, the self expends about the values and goals.

2. Warm relating of self to other

Psychologically healthy people are able to show intimacy (love) to their surroundings. Healthy people have unconditional love with each other. Then healthy people can also feel pain, suffering, fear, and failure. Therefore, people who are maturing must be able to feel that and be able to survive. Healthy people are also able to communicate with each other, and adults understand how to communicate between people. They can be wise in acting and speaking.

\section{Emotional Security}

A healthy personality is able to control emotions themselves. A mature person will not easily give up on his weaknesses. It can be used as life learning. Someone who is mature will not be easily angry or change his emotions for no reason. They can maintain their emotions. 


\section{Self-objectification}

A mature people view their world objectively, he accepts reality as it is. He does not need to change reality to suit his wants, his needs, his delusions and his fears.

5. Skills and Assignments

Healthy people show success at work and also, they will use their skills enthusiastically, involve and put themselves fully in work and duties. In their work and duties, they take responsibility in performing them. So, this is a characteristic of maturity.

\section{Self-Awareness}

Someone who health and mature will be open to the opinions of others. People who have a high level of self-awareness will be wise to others and will be acceptable by others too.

7. Philosophy of life

A mature people look forward, prompted by long term goals and plans. This encouragement is a direction that guides a person toward a goal and gives that person a reason for life.

\section{RESEARCH METHODOLOGY}

This research is called qualitative research because this research presents the descriptive data, in forms of word, spoken or written by people. There are two classified sources of the data such as the primary data and the second data. The primary data are taken from a novel The Alchemist by Paulo Coelho because has a lot of signs. It can relate to discuss with this theory, then the secondary data are support of primary data. It is supporting references such as books and website that related. The first thing to do is to collect the data of primary and secondary sources taken from the text. The researcher's data is using words, sentences and phrases then the data are classified based on the semiotics theory by Charles Sanders Peirce and then analyze and explains to indicate the possibilities of semiotics theory. The data are interpreted to analyze the symbols of the virtue influence to maturity.

\section{FINDINGS}

\section{The Symbols of the Virtue}

5 character symbols and 1 object symbol are found in the novel. In brief, the data is presented as follows:

\begin{tabular}{|c|c|c|c|c|c|}
\hline No & Representamen/Sign & Object & Interpretant & $\begin{array}{l}\text { Page of the } \\
\text { excerpt }\end{array}$ & Amount \\
\hline 1. & A Shepherd & $\begin{array}{l}\text { A boy named } \\
\text { Santiago from } \\
\text { Andalusia who } \\
\text { has a dream as }\end{array}$ & $\begin{array}{l}\text { A human heart, where } \\
\text { humans are required to } \\
\text { always follow their hearts } \\
\text { so as not to get lost. The } \\
\text { human heart acts as a guide }\end{array}$ & $\begin{array}{l}\text { Page } \\
3,6,131,134- \\
135\end{array}$ & 8 \\
\hline
\end{tabular}


Prologue: Journal on Language and Literature Vol.7 No.2 (2021)

\begin{tabular}{|c|c|c|c|c|c|}
\hline & & traveler & $\begin{array}{l}\text { in making decisions and as } \\
\text { a guide to where the } \\
\text { treasure is. }\end{array}$ & & \\
\hline 2. & Melchizedek & $\begin{array}{l}\text { The King of } \\
\text { Salem } \\
\text { disguised as an } \\
\text { old man }\end{array}$ & $\begin{array}{l}\text { A wise king who has the } \\
\text { power or strength to save } \\
\text { Santiago. }\end{array}$ & $\begin{array}{l}\text { Page 23, 24, } \\
25\end{array}$ & 7 \\
\hline 3. & The Stone & $\begin{array}{l}\text { The stone Urim } \\
\& \text { Thummin }\end{array}$ & $\begin{array}{l}\text { The Stone as the spirit for } \\
\text { Santiago to continue his } \\
\text { trip to realize his dream } \\
\text { (treasure). }\end{array}$ & $\begin{array}{l}\text { Page 31, 43- } \\
44\end{array}$ & 4 \\
\hline 4. & A Crystal Shop & $\begin{array}{l}\text { The crystal } \\
\text { merchant }\end{array}$ & $\begin{array}{l}\text { An old man who lives } \\
\text { alone by selling the crystal } \\
\text { who has a religious } \\
\text { personality and as a savior } \\
\text { for Santiago when he lost } \\
\text { his money. }\end{array}$ & Page 48,49 & 3 \\
\hline 5. & Fatima & $\begin{array}{l}\text { A beautiful } \\
\text { woman from } \\
\text { the desert }\end{array}$ & $\begin{array}{l}\text { Santiago loves a wise } \\
\text { woman who is able to } \\
\text { understand Santiago and } \\
\text { accept his flaws. }\end{array}$ & $\begin{array}{l}\text { Page 102, } \\
128\end{array}$ & 4 \\
\hline 6. & The Alchemist & $\begin{array}{l}\text { An Arabian } \\
\text { who has } \\
\text { extraordinary } \\
\text { Powers }\end{array}$ & $\begin{array}{l}\text { A teacher who gives a lot } \\
\text { of life lessons to Santiago } \\
\text { development a better } \\
\text { understanding of life. }\end{array}$ & $\begin{array}{l}\text { Page 69, 84, } \\
136\end{array}$ & 4 \\
\hline
\end{tabular}

Based on the table, there are the symbols of the virtue have been identified using semiotics theory by Charles Sanders Peirce about the triangle model. There are representamen or sign, objects, and interpretant. Furthermore, the researcher found 18 excerpts of the virtue in the novel.

\section{The Influence of the Symbols of Virtue on Maturity}

After identifying the symbols of the virtue, the researcher analyzed about the symbols of the virtue influenced the main character to maturity. There are seven criteria of maturity, extension of self, warm relating of self to other, emotional control, realistic, skills and assignments, self-awareness and philosophy of life, and the findings are displayed in the following table.

Table: 3 The influences of the symbols of virtue in The Alchemist

\begin{tabular}{lclll}
\hline No & Symbols of virtue & $\begin{array}{c}\text { Criteria of } \\
\text { maturity }\end{array}$ & Page of excerpt & Amount \\
\hline 1. & A Shepherd & Extension of self & Page 11, 16, 71\&51 & 3 \\
2. & $\begin{array}{c}\text { Fatima and all of the } \\
\text { symbols of virtue }\end{array}$ & $\begin{array}{l}\text { Warm relating } \\
\text { of self to other }\end{array}$ & Page 100, 125, 128 & 3 \\
3. & The Alchemist & $\begin{array}{l}\text { Emotional } \\
\text { control }\end{array}$ & Page 136,139 & 2
\end{tabular}


Prologue: Journal on Language and Literature Vol.7 No.2 (2021)

\begin{tabular}{|c|c|c|c|}
\hline 4. & The Stone & Realistic & Page 27 \\
\hline 5. & The Crystal Shop & $\begin{array}{l}\text { Skills and } \\
\text { assignments }\end{array}$ & Page $58,62,63$ \\
\hline 6. & The Alchemist & Self-awareness & Page 105 \\
\hline 7. & $\begin{array}{l}\text { Melchizedek and } \\
\text { The Alchemist }\end{array}$ & $\begin{array}{l}\text { Philosophy of } \\
\text { life }\end{array}$ & Page 11 \\
\hline
\end{tabular}

Based on the table, the researcher revealed that the symbols of the virtue can effect a person's maturity. It is evident from the result of the analysis that the researcher has found seven criteria of maturity that influence the symbols of virtue.

\section{DISCUSSION}

\section{The Symbols of Virtue}

In this research, there are six the symbols of the virtue and this section is an analysis of the data has been obtained in the novel The Alchemist by Paulo Coelho.

1. A shepherd

A shepherd is a symbol of human heart, because human heart is able to control their emotion or desire, then the sheep is a symbol of human desires. shepherd is a person who looks after sheep. Also, a shepherd is a caretaker or keeper who is charge of livestock. Besides that, a shepherd is a noble work, because shepherd's work is the most difficult and dangerous work, also he must have high patience to care his livestock.

He saw to it that all the sheep entered through the ruined gate, and then laid some planks across it to prevent the flock from wandering away during the night. There were no wolves in the region, but once an animal had strayed during the night, and the boy had had to spend the entire next day searching for it. (Coelho, p.3)

It can be seen how Santiago keeps and raise his livestock. He has to search for his sheep. The shepherd is a guide and keeper of sheep or goats. He is responsible for his sheep, often count for them and protect him from outside danger. It is the same as humans, while the sheep as a symbol of human's desire, then Santiago as a shepherd has a symbol as a human heart. So that he must maintain his heart because it will easily get lost.

\section{Melchizedek/The King of Salem}

Melchizedek or The King of Salem is a symbol of a teacher because the king is someone who has the power and has a high knowledge. The King or Melchizedek is a wise person and has a lot of life experience. The King as a symbol of a teacher.

To realize one's destiny is a person's only real obligation. All things are one. 
Prologue: Journal on Language and Literature Vol.7 No.2 (2021)

"And, when you want something, all the universe conspires in helping you to achieve it." (Coelho, p.23)

The King gives advice to motivated Santiago to achieve his destiny. The King says that the universe conspires in helping us to achieve what we want. That is why, the human should not be afraid to dream, because nothing is impossible if we truly want to make it happen.

\section{The Stone}

This stone has meaning as the spirit to protect Santiago in continuing his journey in search of the treasure.

"They are called Urim and Thummim. The black signifies 'yes' and the white signifies 'no'. When you are unable to read the omens, they will help you to do so. Always ask an objective question." (Coelho, p.31)

The stone is one of the embodiments of The King to help Santiago. Then, it has the function to give information or instruction to Santiago when he has lost his way or when he is in the middle of his problem. The stone can encourage Santiago to continue his journey, because the spirit often comes not in the form of human beings but looks like something outside of human beings, like advice, support, prayer or even experience.

\section{The Crystal Merchant/The Crystal Shop}

The crystal merchant has a crystal shop in Tangier. In the middle of Santiago's journey to realize his dream, he gets into a trouble. A man steals his money, making him penniless. Because of that, he works at the crystal shop for several months to get some money. He hopes to get enough money to continue his journey. The Crystal Merchant works as a savior for Santiago.

"Let's go and have some lunch," said the crystal merchant.

"You didn't have to do any cleaning," he said "The Koran requires me to feed a hungry person."

"Well then, why did you let me do it?" the boy asked

"Because, the crystal was dirty. And both you and I needed to cleanse our minds of negative thoughts." (Coelho, p.48)

There is a philosophy about the crystal and to keep it clean. When the crystal is dirty, it seems to mirror our mind and our heart that is affected by negative thinking. It needs to be cleaned with our worship so that we are renewed with a clear heart and mind.

\section{Fatima}

Fatima is a symbol of love for Santiago, and only with love his dreams can be achieved. She makes Santiago excited to continue his journey.

"Now it will be with hope. My father went away one day, but he returned to my mother and he always come back since then."

"I'll return, just as your father came back to your mother," he said. (Coelho, p.128) 
Fatima is a wise woman. It can be seen from her attitude that she supports Santiago to achieve his dream. Fatima teaches us about loyalty and unrestricted love. Then, love exists in this world to make humans become better. It guides people to know the truth about ourselves and make us to be wise.

6. The Alchemist

The Alchemist is a person who has the power to help or a savior. He lives for 200 years old and he understands about the soul of the world, then he is able to turn lead and copper into gold.

"You will never be able to escape from your heart. So, it's better to listen to what it has to say. That way, you'll never have to fear an unanticipated blow." (Coelho, p.136)

The Alchemist teaches Santiago to always follow his heart to find out where his treasure is. In fact, humans cannot be separated from his heart, because they have feelings and instincts that must be used to do something. The heart is used to limit ourselves, so we do not over do things. If we can understand our hearts, hopefully everything will be alright.

\section{The Influence of the Symbols of Virtue on Maturity}

In this section, the researcher would like to explain about the influence of the symbols of virtue on Santiago's maturity. The explanation will be divided based on the 7 criteria of maturity.

\section{Extension of self}

When our self develops, we will expand to reach many people or object. Similar to Santiago, in this novel he is a shepherd. Santiago really loves his work as a shepherd, because a shepherd can make him learn about the world from the sheep. Also, the purpose of his life is wandering, he likes to travel. Because of that, Santiago has the courage to make a decision as a shepherd and he uses his heart. He always listens to his heart to achieve his dream. His heart can lead him to realize his goals to be a shepherd and seek the treasure.

The boy knew a lot of people in the city. That was what made travelling appeal to him - he always made new friends and he didn't need to spend all of his time with them. When someone sees the same people every day, as had happened with him at the seminary, they wind up becoming a part of that person's life. (Coelho, p.16)

From that statement above, Santiago's mindset towards maturity can be seen. It is related about extension of self. When people mature, they develop concerns outside themselves. It is not enough to interact with something or someone outside of themselves.

2. Warm relating of self to other

Psychologically healthy people are able to develop intimate relationships with parents, children, partners and friends. This is the result of the extension of self and a feeling of self- 
identity that develops well. People who grow up have a good relationship with their surroundings, such as friendships or love. In the novel, there is only one person who makes Santiago feel loved, she is Fatima.

"I want to stay at the oasis," the boy answered. "I've found Fatima and as far as I'm concerned, she's worth more than treasure." (Coelho, p.125)

Santiago has a relationship with Fatima. He really loves her. It can be found when he said that Fatima is worth more than treasure. Santiago is psychologically healthy. It is shown in a warm relationship with Fatima. People who have maturity in relationship with others, they will show their love to one another. Their maturity is seen when they develop themselves in the circle of life and they realize that we must have a good relationship with others as being social creatures.

\section{Emotional Security}

A healthy personality is one who is able to accept all aspects of his self, including weaknesses without passively giving in to those weaknesses. It can be seen when Santiago realizes his weakness in understanding his own heart. However he does not give up on that, he tries to listen to his heart.

He lost his fear, and forgot about his need to go back to the oasis, because, one afternoon, his heart told him that it was happy. (Coelho, p.136)

At this stage, Santiago can control himself against the fear, he feels and he is able to control it without hiding his feelings because he learns to deal with life fears. Furthermore, another quality of emotional security is "patience with disappointment" where the disappointment experienced is not paralyzing but strengthen them. It shows how a person reacts to pressure and obstacle to various desires or wills. They are able to think of different ways to achieve the same goal.

4. Realistic

One of the characteristics of maturity is realistic. Realistic are people who have an objective view. They accept reality as it is and do not change the reality as they wish.

...the stones could fall thought any time they wanted. He had learned that there were certain things one shouldn't ask about, so as not to flee from one's own decisions.

"I promised that I would make my own decisions," he said to himself. (Coelho, p.43)

In this research, the stone can make Santiago mature because it is a gift from The King of Salem. It has the function to help Santiago in making decision during his journey. Santiago realizes that he does not need the stone yet. He must realistically look at the situation he faces without changing realities to fit his desires, needs and fantasies or fears. 


\section{Skills and Assignment}

The maturity of someone can be seen from their success in their work. People who have healthy personalities will show certain skills or talents according to their ability level. They can use their skills enthusiastically. Also, they have a strong commitment to be able to do something like a job or task. The researcher analyzes that Santiago's maturity when he works in a crystal shop. Santiago shows his success in working there for eleven months.

"You have been a real blessing to me. Today, I understand something I didn't see before..." (Coelho, p.60)

That quote shows that the crystal merchant is proud of Santiago who has helped him a lot. Santiago has proven his success at work. He is able to take responsibility for his work and assignment. Humans seem to be able to complete work and be able to take responsibility in their work so as to give a feeling of quantity for life. Maturity and psychological health cannot be achieved without carrying out important activities and doing so with full dedication, commitment, and skills.

\section{Self-Awareness}

Self-awareness is the ability to see similarities and differences between the ideal self-image with the condition of the real self, being able to see the strengths and weaknesses of oneself. In fact, understanding yourself is a difficult task. This takes effort to understand oneself throughout life objectively. In the case of Santiago, gaining an adequate understanding of himself requires an understanding of himself according to the real situation. If the self-image is getting closer to the real situation, the individual is becoming more mature.

"I'm learning the language of the world and everything in the world is beginning to make sense to me... even the flight of the hawks." he said to himself. And, in that mood, he was grateful to be in love. When you are in love, things make even more sense, he thought. (Coelho, p.105)

That is the strength of Santiago. He learns the language of the world. He is able to understand it because of him being in love. At this stage Santiago reaches a higher level of understanding himself.

Someone who has a high level of self-understanding will be wise towards others and will be better received by others. He can judge others carefully, and does not look down on others. $\mathrm{He}$ is also able to laugh at himself through healthy humor.

\section{Philosophy of life}

The purpose of life is important, because it can motivate us. However, sometimes there are some people who have a philosophy of life as the basic of all life. A healthy person looks forward, driven by long-term goals and plans. He has a feeling of purpose, a feeling of duty to work to the end as the cornerstone of his life. 
It's the possibility of having a dream come true that makes life interesting, he thought, as he looked again at the position of the sun and hurried hid pace. (Coelho, p.11)

That is of the purpose of Santiago's life. He always wants to achieve all his dreams, which is to become a shepherd so he can wander and look for the treasure in the Pyramid. From the purpose of his life, he knows his step, he understands his life, he can guide himself towards a goal, and provide himself a reason for living. Therefore, Santiago becomes a mature person because he has all these criteria for maturity.

\section{CONCLUSION}

Based on the result of the research, there are found seven symbols are reflected in the Alchemist's novel such as A Shepherd, An Old Gypsy Woman, Melchizedek, The Stone, The Crystal Merchant, Fatima and The Alchemist. These symbols shows virtue to influence someone to maturity. The researcher identified these symbols with semiotic triangle then the researcher found the meaning of these symbols. Also, There are seven criteria of maturity found in the novel, such as extension of self, have a good relationship, emotional control, realistic, skill and assignments, self-awareness and philosophy of life. All of them are influenced by the symbols of virtue in the novel.

\section{References}

Alex, S. (2009) Psikologi Umum. Bandung: CV. Pustaka Setia

Chandler, D. (2002) The Basic Semiotics. New York: Routledge. . (2007) Semiotics: The Basic Second Edition. New York: Taylor \& Francis

Danesi, Marcel. (2010) Pesan, Tanda, dan Makna: Buku Teks Dasar Mengenai Semiotika dan Teori Komunikasi. Yogyakarta: Jalasutra.

Eco, U. (1986) Semiotics and Philosophy of Language. Bloomington: Indiana University Press.

Golden, J., et al. (1994) A Semiotic Perspective of Text: The Picture Story Book Event. Journal of Reading Behavior

Jabrohim. (1994) Teori Penelitian Sastra. Yogyakarta: Masyarakat Poetika Indonesia IKIP Muhammadiyah Yogyakarta.

Landy, J.V. (1972) Insight: A Study of the Short Story. Manila: Jesuit Educational Association

Pradopo, R. D. (1994) Prinsip-prinsip Kritik Sastra. Yogyakarta: Gadjah Mada University Press.

Peirce, C. S. (1958) Selected Writings. Great Britain: Dover Publication

Semi, A. (1988) Kritik Sastra. Bandung: Angkasa

Schultz, D. (1991) Psikologi Pertumbuhan, Model-Model Kepribadian Sehat. Yogyakarta: Kanisius. 
Prologue: Journal on Language and Literature Vol.7 No.2 (2021)

Schwarz, D. (1986) The Humanistic Heritage: Critical Theories of the English Novel from James to Hillis Miller. Houndmills: The Mac Millan Press

Soemanto, W. (1998) Psikologi Pendidikan. Bandung: Rineka Cipta.

Stone, R. (2000) "A Semiotic Analysis of Four Designer Clothing Advertisement," dari (htttp://www.aber.uc.uk/media/Students/rbs9701.html. diakses 10 Juli 2019, jam 22.00)

Suryabrata, S. (1998). Psikologi Pendidikan. Jakarta: PT. Raja Grafindo Persada.

Suryabrata, S. (2005). Pengembangan Alat Ukur Psikologis. Yogyakarta: Andi.

Wellek, R. \& Warren, A. (1995). Teori Kesusastraan (terjemahan oleh Budianta). Jakarta: Gramedia.

Zagzebski, L. T. (1996). Virtues of the mind. New York. 